\title{
Article
}

\section{Acclimation to Ex Vitro Conditions in Ninebark}

\author{
Katarzyna Jagiełło-Kubiec, Karolina Nowakowska (D, Aleksandra Józefina Łukaszewska and Andrzej Pacholczak *
}

Citation: Jagiełło-Kubiec, K.;

Nowakowska, K.; Łukaszewska, A.J.; Pacholczak, A. Acclimation to Ex Vitro Conditions in Ninebark. Agronomy 2021, 11, 612. https:// doi.org/10.3390/agronomy11040612

Academic Editor: Giovanni Iapichino

Received: 26 February 2021

Accepted: 21 March 2021

Published: 24 March 2021

Publisher's Note: MDPI stays neutral with regard to jurisdictional claims in published maps and institutional affiliations.

Copyright: (c) 2021 by the authors. Licensee MDPI, Basel, Switzerland. This article is an open access article distributed under the terms and conditions of the Creative Commons Attribution (CC BY) license (https:/ / creativecommons.org/licenses/by/ $4.0 /)$.
Section of Ornamental Plants, Faculty of Horticulture and Biotechnology, Warsaw University of Life Sciences (SGGW), 166 Nowoursynowska str., 02-787 Warszawa, Poland; jagiello.kubiec@gmail.com (K.J.-K.); karolina_nowakowska@sggw.edu.pl (K.N.); aleksandra_lukaszewska@sggw.edu.pl (A.J.Ł.)

* Correspondence: andrzej_pacholczak@sggw.edu.pl

Abstract: Acclimation is the final phase of micropropagation and often decisive for its economic output. The aim of the experiments was to evaluate the effect of abscisic acid (ABA) and supplementary light on acclimation and leaf anatomy of the in vitro-rooted plants of ninebark (Physocarpus opulifolius L.). The initial material came from $8-10$-week-old in vitro cultures on $\frac{1}{2} \mathrm{MS}$ supplemented with $1 \mathrm{mg} \cdot \mathrm{L}^{-1}$ IBA. After potting, plantlets were sprayed with ABA solutions or distilled water and were grown either under natural daylight or under supplemental sodium light at $230 \mu \mathrm{mol} \cdot \mathrm{m}^{-2} \cdot \mathrm{s}^{-1}$ between 2 and 9 p.m. All measurements and anatomical observations were done after eight weeks in the greenhouse. Supplementary lighting significantly increased the percentage of acclimatized plants, plant height and the internode number. Plant growth was also positively affected by $1 \mathrm{mg} \cdot \mathrm{L}^{-1} \mathrm{ABA}$. During acclimation, the photosynthesis rate increased while the transpiration and stomatal conductance dropped. The assimilation pigment contents increased under supplemental lighting while ABA had no detectable effect. However, relative to water controls, ABA increased photosynthesis, reduced transpiration, and stomatal conductance in plants growing under both light conditions. Leaves from the in vitro plants were about two times thinner than those from plants growing in soil, with only a single layer of the palisade parenchyma, hence with lower proportion in relation to the spongy parenchyma. Supplementary light during acclimation increased leaf thickness but only in the water control while it decreased it in the ABA-treated plants. ABA increased the mesophyll thickness but only in plants growing under natural light. In conclusion, supplementary light and treatment with ABA enhance acclimation of micropropagated ninebark plants.

Keywords: leafy shrubs; microplants; ABA; leaf anatomy; chlorophyll; gas exchange

\section{Introduction}

Transfer of rooted micro cuttings to the greenhouse is the final phase of micropropagation, and its success rate is often decisive for the economic outcome of the entire process. Properly done, acclimation has a crucial impact on quality, hence on the commercial value of plants. During this transition phase, plants are subjected to stressful conditions such as drastically lower relative air humidity, air movement and different light intensity [1-3]. Excessive stress conditions such as drought or oxidative stress can lead to plant death. Acclimation of microplants to exogenous conditions is often the most difficult part of the in vitro propagation protocols, and still remains a bottleneck in micropropagation of numerous species $[2,4]$.

Physiological disorders leading to death of micropropagated plants are mainly due to excessive water loss caused by improper stomata function, lack of wax on leaf surface, thin epidermis, and malfunctioning root system $[3,5]$. The main problem in controlling the transpiration of the in vitro cultured plants is poor stomatal function, which is a consequence of a limited plant capability to produce abscisic acid (ABA) [6]. ABA plays a key role in many physiological processes, including responses to abiotic stresses and the control of stomata action [7]. Water deficit and salt stress result in ABA accumulation, which leads to stomatal closure, decreasing transpiration and water loss [8]. Because of 
that, $\mathrm{ABA}$ is often used during acclimation to ex vitro conditions and its foliar application increases the survival rate of the explants [9].

To avoid losses, rooted microcuttings should be planted into soil and placed in a greenhouse where the air humidity can be gradually lowered. Fungicides should be used, as well as antitranspirants, which protect plantlets against water stress [10]. It appears that an increase in the survival rate of micropropagated material is associated with the improvement of photosynthetical abilities of plants under increased light intensity provided during acclimation [11].

Ninebark has recently gained enormous popularity and is massively planted in green areas. However, as the rooting rate of stem cuttings ranges widely among cultivars (50-85\%), at times falling below the economic threshold of ca. 50\% [12], the conventional propagation methods are not sufficiently effective. The in vitro micropropagation appears as an effective alternative to the standard propagation by cuttings, as it is capable of producing large quantities of the true-to-type plant material. The aim of the experiments was to evaluate the effect of ABA and supplementary light on acclimation and the leaf anatomy in the in vitro-rooted ninebark cuttings Physocarpus opulifolius L. cultivar Diable d'Or Mindia.

\section{Material and Methods}

All experiments were done on the red ninebark (Physocarpus opulifolius L.) cultivar Diable d'Or Mindia. The initial material came from 8-10-week-old in vitro culture growing on $1 / 2 \mathrm{MS}$ supplemented with $1 \mathrm{mg} \cdot \mathrm{L}^{-1}$ IBA [13]. Plants were at least $3.5 \mathrm{~cm}$ high, on average had 9 internodes and 4-6 roots not shorter than $1 \mathrm{~cm}$. After taking the plants out of the culture jars, roots were rinsed in distilled water to remove the medium remnants, and planted into P9 pots $(9 \mathrm{~cm}$ in diameter) filled with a sterile substrate (de-acidified white peat and perlite, $v / v$ 1:2). These were placed into transparent containers (Curver 33 l). To avoid a pathogen invasion, plants were sprayed with a fungicide mixture (Topsin SC $0.15 \%$ plus Captan $0.2 \%$ ). To maintain constant air humidity, the containers were closed with transparent covers and placed in a greenhouse under $25 / 20{ }^{\circ} \mathrm{C}$. After one week, the containers were being gradually uncovered to slowly acclimatize plants to ex vitro conditions. Relative humidity in the greenhouse was not controlled. Eight weeks after planting, the percentages of acclimatized plants, their heights and internode numbers were scored. Each treatment contained 5 replicates with 10 plants each (50 plants in total).

To evaluate the effect of ABA on acclimation to greenhouse conditions, plants were sprayed either with distilled water (the control treatment) or with ABA in concentration: $0.5,1$ or $2 \mathrm{mg} \cdot \mathrm{L}^{-1}$. The effects were evaluated after 8 weeks in the greenhouse.

To assess the effect of both, the ABA and supplemental light plants were sprayed with $1 \mathrm{mg} \cdot \mathrm{L}^{-1} \mathrm{ABA}$ or distilled water and placed in the greenhouse. One half of the containers were placed on a table lighted with sodium lamps with light of $230 \mu \mathrm{mol} \cdot \mathrm{m}^{-2} \cdot \mathrm{s}^{-1}$ (measured with radiometer-photometer RF-100 Sonopan, PPUH SONOPAN Sp. z o.o., Białystok, Poland) between 2 and 9 p.m., the other half of the containers were placed on a bench with no supplemental light. The experiment was started on December 10, with daylight between 7.30 a.m. and 3.30 p.m. On cloudy days, the light intensity over non-lighted plants was ca $50 \mu \mathrm{mol} \cdot \mathrm{m}^{-2} \cdot \mathrm{s}^{-1}$.

For the chlorophyll contents measurements, the above-ground plant parts were finely chopped, mixed, and $0.250 \mathrm{mg}$ samples were taken. Some samples were used immediately to determine the dry weight while the rest were stored under $-80^{\circ} \mathrm{C}$. Three extracts were prepared for each treatment, three aliquots were taken from each extract, and three readings were made for each aliquot, producing nine readings for each data point. The initial pigment concentration was measured in one batch of leaves sampled from several plants. Chlorophyll $\mathrm{a}+\mathrm{b}$ and carotenoids were determined according to Lichtenthaler and Wellburn [14]. Absorbance was measured with a spectrophotometer UV-1601 PC (Shimadzu, Columbia, MD, USA), at 646, 652, and $663 \mathrm{~nm}$, against $80 \%$ acetone. The pigment contents were calculated per gram of dry weight and given as $\mathrm{mg} \cdot \mathrm{g} \mathrm{DW} \mathrm{DW}^{-1}$. 
The gas exchange parameters were measured using a portable LICOR LI-6400XT apparatus (LI-COR Biosciences GmbH, Bad Homburg, Germany). Plant leaves wee individually placed in the device chamber where conditions were standardized to $\mathrm{CO}_{2}$ concentration at $400 \mu \mathrm{mol} \cdot \mathrm{mol}^{-1}$, PPFD (photosynthetic photon flux density) $800 \mu \mathrm{mol} \cdot \mathrm{m}^{-2} \cdot \mathrm{s}^{-1}$, flow $400 \mu \mathrm{mol} \cdot \mathrm{s}^{-1}$, and the relative humidity at $30-40 \%$. The actual and calculated readings were processed by Microsoft Excel. The photosynthetic rate $\left(\mu \mathrm{mol} \mathrm{CO}_{2} \cdot \mathrm{m}^{-2} \cdot \mathrm{s}^{-1}\right)$, the transpiration rate $\left(\mathrm{mmol} \mathrm{H} \mathrm{H}_{2} \mathrm{O} \cdot \mathrm{m}^{-2} \cdot \mathrm{s}^{-1}\right)$, and stomatal conductance were measured ( $\mathrm{mmol}$ $\left.\mathrm{H}_{2} \mathrm{O} \cdot \mathrm{m}^{-2} \cdot \mathrm{s}^{-1}\right)$. The measurements were made on the fourth leaf from the top of a plant, on 15 plants; i.e., three leaves from each of five replicates. The initial measurements were done before spraying plants.

For anatomical observations, the central parts $(0.5 \times 0.5 \mathrm{~cm})$ of five leaf blades situated in the fourth node from the shoot tip of the in vitro-rooted plants were taken before potting and after 8 weeks of cultivation in the greenhouse. The samples from the soil-grown plants were taken from leaves in the same location on young shoots at the beginning of July. The material was fixed in FAA (a 16:5:50 $\mathrm{v} / \mathrm{v} / \mathrm{v}$ mixture of formaldehyde, glacial acetic acid, and $96 \%$ ethanol), dehydrated through graded ethanol and the xylene series, and embedded in paraffin [15]. The paraffin blocks were cut with the rotary microtome Leica RM 2255 (Leica Biosystems, Nussloch, Germany) into $10 \mu \mathrm{m}$ sections and stained with safranin-fast green. Photographs were taken under the Olympus BX-41 microscope (Olympus Optical Co. Ltd, Tokyo, Japan) equipped with Olympus Camedia C5050 (Olympus Optical Co. Ltd, Tokyo, Japan) with a threefold optical magnification and 5 megapixel matrix, and recorded in the .jpg format. The measurements of each parameter were made on five photographs using the M.I.S. Quick PHOTO 3.1 Pro software (PROMICRA, Prague, Czech Republic).

All results were subjected to the analysis of variance using the Statgraphics Centurion XVI (Statgraphics Technologies Inc., The Plains, VA, USA), after the Shapiro-Wilk test. Arcsine transformation was performed for all data in percentages. Experimental data were subjected to one- or two-way analysis of variance and then to Tukey's multiple range test to separate the means at the significance level at $\alpha=0.05$ [16].

\section{Results}

\subsection{The Effect of $A B A$}

The mean percentage of acclimated plants was $90 \%$ with no significant differences between treatments. The tallest plants $(5.7 \mathrm{~cm})$ with the highest internode number (11.3) were those sprayed with $1 \mathrm{mg} \cdot \mathrm{L}^{-1}$ ABA (Table 1). Plants from other treatments reached $5.0-5.3 \mathrm{~cm}$ with no significant differences; the lowest internode numbers were in the control treatment (9.5 per plant).

Table 1. The effect of abscisic acid (ABA) in different concentrations on acclimation of ninebark microplants to the ex vitro.

\begin{tabular}{cccc}
\hline $\begin{array}{c}\text { ABA } \\
\text { Conc. }\left[\mathbf{m g} \cdot \mathbf{L}^{-1} \text { ] }\right.\end{array}$ & $\begin{array}{c}\text { Percentage of } \\
\text { Acclimated Plants [\%] }\end{array}$ & Plant Height [cm] & Internode Number \\
\hline 0 (Control) & $88.0 \pm 4.58 \mathrm{a} *$ & $5.2 \pm 0.41 \mathrm{a}$ & $9.5 \pm 0.69 \mathrm{a}$ \\
0.5 & $90.0 \pm 6.17 \mathrm{a}$ & $5.3 \pm 0.11 \mathrm{a}$ & $10.2 \pm 0.81 \mathrm{~b}$ \\
1.0 & $90.0 \pm 5.28 \mathrm{a}$ & $5.7 \pm 0.23 \mathrm{~b}$ & $11.3 \pm 0.43 \mathrm{c}$ \\
2.0 & $92.0 \pm 8.85 \mathrm{a}$ & $5.0 \pm 0.15 \mathrm{a}$ & $10.3 \pm 0.88 \mathrm{~b}$ \\
\hline${ }^{*}$ Means in a column followed by the same letter do not differ significantly at $\alpha=0.05 .{ }^{* *} 100 \%$ were 50 microplants.
\end{tabular}

\subsection{The Effect of $A B A$ and Supplemental Light}

Plants under natural light both treated and not treated with ABA acclimated at $90 \%$, i.e., significantly less than plants after ABA treatments plus supplemental light, where acclimation was $100 \%$ (Table 2). The shortest were plants sprayed with ABA and under natural light, which reached $4.5 \mathrm{~cm}$; the tallest were those under supplemental light $(7.5-7.7 \mathrm{~cm})$. Supplemental light significantly increased the node number: from 9.9 to 12.6 in the water-sprayed plants and from 10.3 to 11.9 in the ABA-treated plants. 
Table 2. The effect of ABA and supplemental light on plant acclimation to ex vitro conditions.

\begin{tabular}{ccccc}
\hline Spraying & Lighting & $\begin{array}{c}\text { Percentage of } \\
\text { Acclimatized } \\
\text { Plants [\%] }\end{array}$ & $\begin{array}{c}\text { Plant Height } \\
{[\mathbf{c m}]}\end{array}$ & $\begin{array}{c}\text { Internode } \\
\text { Number }\end{array}$ \\
\hline $\mathrm{H}_{2} \mathrm{O}$ & - & $90.0 \pm 7.16 \mathrm{a} *$ & $4.9 \pm 0.58 \mathrm{~b}$ & $9.9 \pm 1.81 \mathrm{a}$ \\
$\mathrm{ABA}$ & & $90.0 \pm 7.16 \mathrm{a}$ & $4.5 \pm 0.66 \mathrm{a}$ & $10.3 \pm 0.92 \mathrm{a}$ \\
$\mathrm{H}_{2} \mathrm{O}$ & + & $94.0 \pm 5.37 \mathrm{~b}$ & $7.7 \pm 0.71 \mathrm{c}$ & $12.6 \pm 1.32 \mathrm{~b}$ \\
$\mathrm{ABA}$ & & $100.0 \pm 0.0 \mathrm{c}$ & $7.5 \pm 0.58 \mathrm{c}$ & $11.9 \pm 1.15 \mathrm{~b}$ \\
\hline
\end{tabular}

* Means in a column followed by the same letter do not differ significantly at $\alpha=0.05 .{ }^{* *} 100 \%$ were 50 microplants.

\subsection{Chloropyll $a+b$ and Carotenoid Contents}

Both treatments, with ABA and supplemental light, significantly affected the levels of chlorophyll A + B and carotenoids. In plants under natural light, the chlorophyll A + B contents were lower than in plants under supplemental light; ABA did not affect the chlorophyll levels. Supplemental light increased the carotenoid concentrations while ABA did not produce a univocal response: the highest carotenoid content was in plants under supplemental light and sprayed with ABA, while the lowest was in the ABA-treated plants growing under natural light (Table 3).

Table 3. The effects of ABA and supplemental lighting on the contents of assimilation pigments in leaves of acclimated ninebark plants cv. Diable D'Or Mindia.

\begin{tabular}{cccc}
\hline Spraying & Supplemental Light & $\begin{array}{c}\text { Chlorophyll A + B } \\
{\left[\mathbf{m g} \cdot \mathbf{g}^{-\mathbf{1}} \mathbf{D W}\right]}\end{array}$ & $\begin{array}{c}\text { Carotenoids } \\
{\left[\mathbf{m g} \cdot \mathbf{g}^{-\mathbf{1}} \mathbf{~ D W} \text { ] }\right.}\end{array}$ \\
\hline $\mathrm{H}_{2} \mathrm{O}$ & - & $3.57 \pm 0.45 \mathrm{a}^{*}$ & $0.81 \pm 0.05 \mathrm{~b}$ \\
$\mathrm{ABA}$ & & $3.34 \pm 0.62 \mathrm{a}$ & $0.74 \pm 0.03 \mathrm{a}$ \\
\hline $\mathrm{H}_{2} \mathrm{O}$ & + & $4.71 \pm 0.49 \mathrm{~b}$ & $1.07 \pm 0.04 \mathrm{c}$ \\
$\mathrm{ABA}$ & & $4.90 \pm 0.41 \mathrm{~b}$ & $1.13 \pm 0.01 \mathrm{~d}$ \\
\hline
\end{tabular}

* Means in a column followed by the same letter $\mathrm{r}$ do not differ significantly at $\alpha=0.05$.

\subsection{Gas Exchange Parameters}

3.4.1. Photosynthetic Rate

Application of ABA before acclimation significantly affected the photosynthesis rate while the supplemental light produced no effect (Table 4). The photosynthetic rate was the lowest on the first day of the experiment and increased 2.8-3.1 times by Day 14, from 1.60 to 4.49-5.00 $\mu \mathrm{mol} \mathrm{CO} \cdot \mathrm{C}^{-2} \cdot \mathrm{s}^{-1}$ with no significant differences between treatments. Further increases were observed on Day 28 in the ABA-treated plants growing under both light regimes. Supplemental light did not affect the photosynthetic rate in any of the treatments nor on the analysis date (Table 4).

Table 4. The effects of ABA and supplemental lighting during eight weeks of acclimation to the ex vitro conditions on the photosynthetic rate $\left(\mu \mathrm{mol} \mathrm{CO} 2 \cdot \mathrm{m}^{-2} \cdot \mathrm{s}^{-1}\right)$ in leaves of ninebark plants cv. Diable D'Or Mindia, measured 14 (Date I) and 28 days (Date II) after planting.

\begin{tabular}{|c|c|c|c|c|c|}
\hline \multicolumn{2}{|c|}{ Treatment } & \multicolumn{3}{|c|}{ Date of Analysis } & \multirow[t]{2}{*}{$\begin{array}{c}\text { Mean } \\
\text { (Treatments) }\end{array}$} \\
\hline Spraying & Supplemental Light & Date 0 & Date I & Date II & \\
\hline $\mathrm{H}_{2} \mathrm{O}$ & \multirow{2}{*}{-} & $1.60 \pm 0.25 \mathrm{a}^{*}$ & $4.69 \pm 0.13 b$ & $5.08 \pm 0.16 b$ & $3.79 \pm 0.13 \mathrm{a}^{* * *}$ \\
\hline $\mathrm{ABA}$ & & $1.60 \pm 0.31 \mathrm{a}$ & $4.85 \pm 0.25 b$ & $5.48 \pm 0.39 c$ & $3.97 \pm 0.15 b$ \\
\hline $\mathrm{H}_{2} \mathrm{O}$ & \multirow{2}{*}{+} & $1.60 \pm 0.20 \mathrm{a}$ & $4.49 \pm 0.40 \mathrm{~b}$ & $4.88 \pm 0.26 b$ & $3.65 \pm 0.25 \mathrm{a}$ \\
\hline $\mathrm{ABA}$ & & $1.60 \pm 0.52 \mathrm{a}$ & $5.00 \pm 0.15 b$ & $5.92 \pm 0.32 c$ & $4.17 \pm 0.30 b$ \\
\hline \multicolumn{2}{|c|}{ Mean (date) } & $1.60 \pm 041 \mathrm{a}^{* *}$ & $4.75 \pm 0.25 \mathrm{~b}$ & $5.34 \pm 0.30 c$ & \\
\hline
\end{tabular}

${ }^{*}$ Means within the table followed by the same letter do not differ significantly at $\alpha=0.05 .{ }^{* *}$ Means in the line followed by the same letter do not differ significantly at $\alpha=0.05$. ${ }^{* * *}$ Means in the column followed by the same letter do not differ significantly at $\alpha=0.05$. 


\subsubsection{Transpiration Rate}

The transpiration rate was the highest on the first day of the experiment $(7.03 \mathrm{mmol}$ $\mathrm{H}_{2} \mathrm{O} \cdot \mathrm{m}^{-2} \cdot \mathrm{s}^{-1}$ ) and by Day 28 it fell to $30 \%-50 \%$ of the initial rate (Table 5). On Date II, the ABA applied to plants under natural light reduced the transpiration by $25 \%$ relative to the water-sprayed plants, while in plants under supplemental light this reduction was nearly $30 \%$. Supplemental light did not significantly affect transpiration.

Table 5. The effects of ABA and supplemental lighting on the transpiration rate $\left(\mathrm{mmol} \mathrm{H} \mathrm{H}_{2} \mathrm{O} \cdot \mathrm{m}^{-2} \cdot \mathrm{s}^{-1}\right)$ in leaves of ninebark plants cv. Diable D'Or Mindia measured 14 (Date I) and 28 days (Date II) after planting.

\begin{tabular}{|c|c|c|c|c|c|}
\hline \multicolumn{2}{|c|}{ Treatment } & \multicolumn{3}{|c|}{ Date of Analysis } & \multirow[t]{2}{*}{$\begin{array}{c}\text { Mean } \\
\text { (Treatment) }\end{array}$} \\
\hline Spraying & Supplemental Light & Date 0 & Date I & Date II & \\
\hline $\mathrm{H}_{2} \mathrm{O}$ & \multirow{2}{*}{-} & $7.03 \pm 0.41 b$ * & $3.68 \pm 0.21 b$ & $3.57 \pm 0.21 b$ & $4.76 \pm 0.25 b^{* * *}$ \\
\hline $\mathrm{ABA}$ & & $7.03 \pm 0.41 b$ & $3.20 \pm 0.11 \mathrm{a}$ & $2.69 \pm 0.15 a$ & $4.31 \pm 0.42 \mathrm{a}$ \\
\hline $\mathrm{H}_{2} \mathrm{O}$ & \multirow{2}{*}{+} & $7.03 \pm 041 b$ & $3.32 \pm 0.24 \mathrm{a}$ & $3.03 \pm 0.08 \mathrm{ab}$ & $4.46 \pm 0.35 \mathrm{ab}$ \\
\hline $\mathrm{ABA}$ & & $7.03 \pm 0.41 b$ & $3.14 \pm 0.23 \mathrm{a}$ & $2.15 \pm 0.40 \mathrm{a}$ & $4.11 \pm 0.20 \mathrm{a}$ \\
\hline \multicolumn{2}{|c|}{ Mean (date) } & $7.03 \pm 0.41 b$ ** & $3.33 \pm 0.44 \mathrm{a}$ & $2.86 \pm 0.11 \mathrm{a}$ & \\
\hline
\end{tabular}

${ }^{*}$ Means within the table followed by the same letter do not differ significantly at $\alpha=0.05 .{ }^{* *}$ Means in the line followed by the same letter do not differ significantly at $\alpha=0.05{ }^{* * *}$ Means in the column followed by the same letter do not differ significantly at $\alpha=0.05$.

\subsubsection{Stomatal Conductance}

The highest stomatal conductance was observed on Day $0\left(0.399 \mathrm{mmol} \mathrm{H}_{2} \mathrm{O} \cdot \mathrm{m}^{-2} \cdot \mathrm{s}^{-1}\right)$ and it dropped on Day 14 in all treatments-to $35 \%-47 \%$ of the initial value (Table 6). In plants growing under natural daylight, $\mathrm{ABA}$ reduced the conductance by $25 \%$ relative to the water-treated plants. Supplemental lighting resulted in slightly (8.5\%) but significantly increased stomatal conductance in the ABA-treated plants as compared to the water-sprayed plants. On Day 28, the stomatal conductance dropped further-by $12-34 \%$ relative to the previous measurements, being the highest in the water-treated plants under supplemental light. Generally, light had no effect on the stomatal conductance parameter while the ABA treatment reduced it under both light regimes.

Table 6. The effects of ABA and supplemental lighting on the stomatal conductance $\left(\mathrm{mmol} \mathrm{H}_{2} \mathrm{O} \cdot \mathrm{m}^{-2} \cdot \mathrm{s}^{-1}\right)$ in leaves of ninebark plants cv. Diable D'Or Mindia measured 14 (Date I) and 28 days (Date II) after planting.

\begin{tabular}{|c|c|c|c|c|c|}
\hline \multicolumn{2}{|c|}{ Treatment } & \multicolumn{3}{|c|}{ Date of Analysis } & \multirow[t]{2}{*}{$\begin{array}{c}\text { Mean } \\
\text { (Treatment) }\end{array}$} \\
\hline Spraying & Extra Light & Date 0 & Date I & Date II & \\
\hline $\mathrm{H}_{2} \mathrm{O}$ & \multirow{2}{*}{-} & $0.399 \pm 0.03 c^{*}$ & $0.187 \pm 0.01 \mathrm{~b}$ & $0.126 \pm 0.01 \mathrm{a}$ & $0.237 \pm 0.03 b^{* * *}$ \\
\hline $\mathrm{ABA}$ & & $0.399 \pm 0.03 c$ & $0.140 \pm 0.02 \mathrm{a}$ & $0.106 \pm 0.01 \mathrm{a}$ & $0.215 \pm 0.03 \mathrm{a}$ \\
\hline $\mathrm{H}_{2} \mathrm{O}$ & \multirow{2}{*}{+} & $0.399 \pm 0.03 c$ & $0.173 \pm 0.03 b$ & $0.153 \pm 0.02 b$ & $0.241 \pm 0.02 \mathrm{~b}$ \\
\hline $\mathrm{ABA}$ & & $0.399 \pm 0.03 c$ & $0.152 \pm 0.01 \mathrm{~b}$ & $0.100 \pm 0.01 \mathrm{a}$ & $0.217 \pm 0.01 \mathrm{a}$ \\
\hline \multicolumn{2}{|c|}{ Mean (date) } & $0.399 \pm 0.04 c^{* *}$ & $0.163 \pm 0.01 b$ & $0.121 \pm 0.01 \mathrm{a}$ & \\
\hline
\end{tabular}

${ }^{*}$ Means within the table followed by the same letter do not differ significantly at $\alpha=0.05 .{ }^{* *}$ Means in the line followed by the same letter do not differ significantly at $\alpha=0.05$. ${ }^{* * *}$ Means in the column followed by the same letter do not differ significantly at $\alpha=0.05$.

\subsection{Anatomical Observations}

\section{Leaf Blade Structure}

Leaf blades of plants growing in vitro had a single layer of the palisade parenchyma, $17.9 \mu \mathrm{m}$ thick. The cells were loosely packed and contained different chloroplast numbers. Thickness of spongy parenchyma was $42 \%$ larger than that of the palisade parenchyma. Wide air spaces were present between few loosely packed cells. The mean thickness of the 
adaxial epidermis was $12.1 \mu \mathrm{m}$ while that of the abaxial epidermis was $10.7 \mu \mathrm{m}$ (Table 7 , Figure 1a).

Table 7. Parameters of the leaf blade anatomy in ninebark Diable D'Or Mindia subjected to ABA treatment and supplemental light during acclimation to ex vitro conditions and growing in vitro and in soil. The results come from three different observations thus they vary in statistical evaluation method.

\begin{tabular}{|c|c|c|c|c|c|c|}
\hline \multirow{3}{*}{ Parameter $[\mu \mathrm{m}]$} & \multicolumn{6}{|c|}{ Mean Value on Cross Section } \\
\hline & \multirow{2}{*}{ In Vitro } & \multicolumn{4}{|c|}{ Acclimatization Condition } & \multirow{2}{*}{ In Vivo } \\
\hline & & $\mathrm{H}_{2} \mathrm{O}$ & ABA & $\mathrm{H}_{2} \mathrm{O}-$ Extra Light & ABA-Extra Light & \\
\hline Adaxial epidermis & $12.1 \pm 0.9 \mathrm{a}^{*}$ & $12.1 \pm 0.25 \mathrm{a}^{* *}$ & $15.8 \pm 0.07 \mathrm{c}$ & $14.5 \pm 0.10 \mathrm{~b}$ & $15.4 \pm 0.15 \mathrm{bc}$ & $13.6 \pm 1.7 \mathrm{~b}$ \\
\hline Palisade mesophyll & $17.9 \pm 1.7 \mathrm{~b}$ & $18.2 \pm 3.18 \mathrm{a}$ & $33.3 \pm 3.16 c$ & $21.2 \pm 2.04 \mathrm{~b}$ & $22.2 \pm 1.14 b$ & $42.3 \pm 4.3 c$ \\
\hline Spongy mesophyll & $31.1 \pm 2.6 c$ & $24.3 \pm 6.66 \mathrm{a}$ & $40.5 \pm 5.00 \mathrm{c}$ & $30.8 \pm 2.88 b$ & $29.0 \pm 3.00 \mathrm{~b}$ & $57.2 \pm 7.5 \mathrm{~d}$ \\
\hline Abaxial epidermis & $10.7 \pm 1.4 \mathrm{a}$ & $7.3 \pm 0.43 \mathrm{a}$ & $7.7 \pm 0.08 \mathrm{a}$ & $9.0 \pm 0.34 b$ & $7.7 \pm 0.08 \mathrm{a}$ & $9.1 \pm 1.5 \mathrm{a}$ \\
\hline Leaf thickeness & 72.0 & $61.7 \pm 4.95 \mathrm{a}$ & $97.3 \pm 9.18 c$ & $75.5 \pm 6.94 b$ & $74.3 \pm 4.10 \mathrm{~b}$ & 122.2 \\
\hline
\end{tabular}

* Means and standard deviations in the column followed by the same letter do not differ significantly at $\alpha=0.05$. ${ }^{* *}$ Means in the line (within the four-column table) followed by the same letter do not differ significantly at $\alpha=0.05$. Means \pm standard deviation followed by the same letter are not significantly different according to Tukey's multiple range test at $\alpha=0.05$.

Supplemental light increased the thickness of all leaf tissues so that the newly developed leaves in the water-sprayed plants were more than $20 \%$ thicker than those in plants growing under natural light. It was spongy parenchyma which responded the best to the supplemental light, by increasing its thickness by $27 \%$. However, ABA affected the leaf structure in a more significant way but only in plants under natural light. Here, three out of four measured anatomy parameters have increased: the adaxial epidermis, and the palisade and spongy mesophylls (Table 7, Figure 1b,c). In general, ABA increased the leaf thickness by $58 \%$ relative to the water control, due to $83 \%$ and $67 \%$ increases in the palisade and spongy parenchyma, respectively. In plants under supplemental lighting, only the abaxial epidermal thickness increased after the ABA treatment (Figure 1d,e, Table 7).

In plants growing in soil (in vivo), the epidermis of the leaf blade consisted of a single layer of tightly appressed cells with walls which were unevenly thickened. The outer cell wall - that exposed to air-was thicker than the other walls of each cell. Under the adaxial epidermis, 2-3 layers of the palisade parenchyma were present, built of elongated cylindrical cells oriented perpendicularly to the leaf surface. These cells contained numerous chloroplasts. Spongy parenchyma built of cells with numerous air channels formed by air spaces was situated at the abaxial side. In the central leaf part, conductive bundles were present (Figure 1f). The thickness of the adaxial epidermis was $13.6 \mu \mathrm{m}$ and that of the abaxial epidermis was $9.1 \mu \mathrm{m} ; 30 \%$ thinner than the adaxial one. The spongy parenchyma was $26 \%$ wider than the palisade parenchyma (Table 7 ).
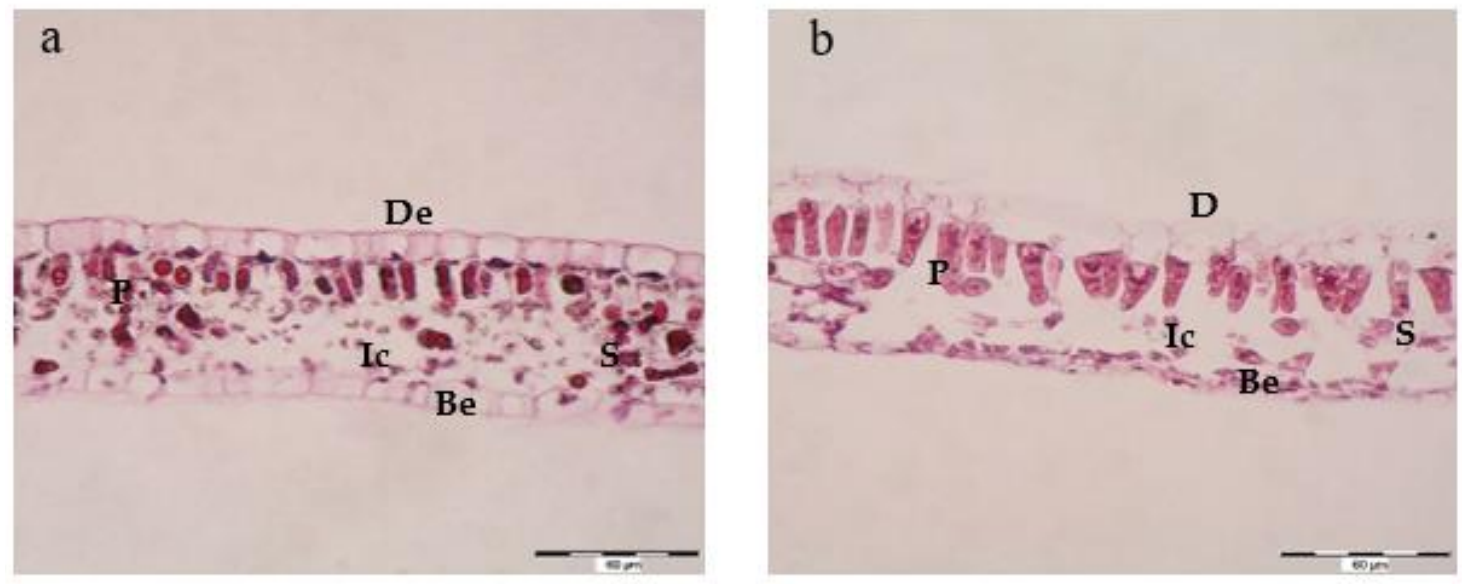

Figure 1. Cont. 

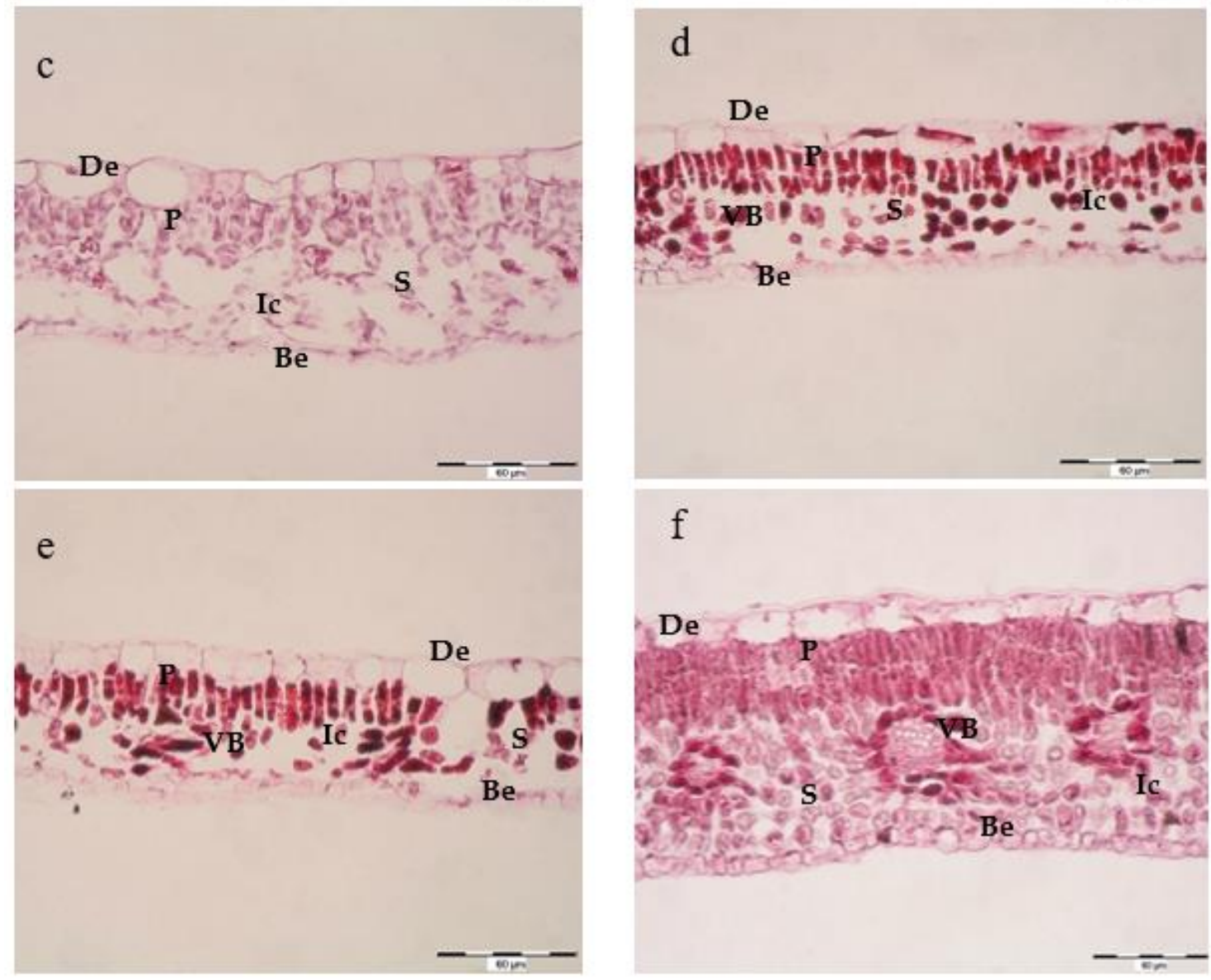

Figure 1. Cross section of ninebark leaf blade in plants of cv. Diable D'Or Mindia growing: (a) in vitro, (b) acclimated to ex vitro conditions—control—-plants sprayed with water, (c) plants sprayed with ABA, (d) plants sprayed with water and given supplemental light, (e) plants sprayed with ABA and given supplemental light, (f) in vivo; De-adaxial epidermis, Be-abaxial epidermis, $\mathrm{P}$ - palisade parenchyma, S—spongy parenchyma, Ic—air spaces, VB-conductive bundle. Magnified $\times 40$.

\section{Discussion}

Specific conditions during in vitro culture cause morphological, anatomical, and physiological abnormalities in plant development. When transferred to ex vitro conditions such plants may easily be damaged due to rapid changes of the growth environment, so they need a period of acclimation. This process can be hastened by acclimation in vitro or after transferring plants into greenhouse conditions. Reducing the transpiration rate, for example by using antitranspirants such as abscisic acid (ABA), is also beneficial [1]. It is a well-established fact that both ABA and light parameters have a major effect on plant acclimation after transfer from in vitro to greenhouse conditions. ABA increases plant tolerance to different environmental stresses, mainly by closing stomata and reducing water loss from leaves [17]. Light affects the growth rate and chlorophyll contents [18].

Addition of ABA to the last subculture of tobacco cuttings increased the survival rate upon transfer from in vitro to natural conditions [18]. In coral bells, $94 \%$ of plants became acclimated after being sprayed with aqueous ABA solution [9]. The ABA treatment positively affected the chlorophyll $\mathrm{a}+\mathrm{b}$ content and photosynthesis parameters, improving the growth of Nicotiana tabacum L. during acclimation [19]. Addition of ABA to the last subculture improved acclimatization of in vitro grown tobacco plants [7]. Seven days after transplantation, their chlorophyll content was higher and their water use efficiency increased significantly [17]. In Ulmus minor Mill., foliar ABA application immediately after the ex vitro transfer improved plant hardening by preventing water loss and enhancing the photosynthetic efficiency [20]. 
In tobacco transferred to ex vitro conditions, the stomatal conductance of leaves was high on the first days of acclimation but dropped following an ABA application [1,18]. However, after 2-3 weeks, the stomatal conductance was similar in control and the ABA treated plants. A similar effect was observed in a study of stomatal conductance in leaves of Vitis vinifera L [21].

Light is another factor that increases the chlorophyll and carotenoid contents as well the photosynthesis rate during acclimation. Already on the first day of acclimation there was more chlorophyll $\mathrm{a}+\mathrm{b}$ in tobacco plants growing under high light intensity than under low light [18]. Most plant species respond well to long day conditions by increasing the leaf area and hence their overall chlorophyll content, and increased photosynthesis rate. Chlorophyll $\mathrm{a}+\mathrm{b}$ absorbs the visible part of light so plants are able to convert it into chemical energy [22]. Already on the first day of acclimation of in vitro grown tobacco plants, there was more chlorophyll $\mathrm{a}+\mathrm{b}$ in plants growing under high light intensity than under low light [18].

In ninebark Diable D'Or Mindia, described here, positive effects of both ABA and supplemental light were clearly evident. Although plants were reasonably well acclimated even after being sprayed with water (88\%), 100\% of plants survived when treated with $1 \mathrm{mg} \cdot \mathrm{L}^{-1}$ ABA and given supplemental light. Plant growth was also positively affected as they were taller with larger node numbers. Plants also responded to ABA application by an increased photosynthesis rate, regardless of the light conditions, contrary to reports of other authors on light-photosynthesis relations. Generally, irradiance is a factor increasing the chlorophyll and carotenoid contents as well the photosynthetic rate during acclimation [1,19].

Manipulating light and reducing transpiration by ABA during acclimatization can modify leaf anatomy [19]. Generally, plants produce thicker and larger leaves under high intensity light [23]. Measurements made on leaves of four species: pea, spinach, pumpkin, and Verbascum phoeniceum L., showed that the total leaf thickness was significantly higher under high light intensity than under low light intensity. Generally, this was due to an increase in the thickness of the palisade parenchyma while in spinach it was the spongy parenchyma that contributed to the increase in leaf thickness [24]. Similarly, Han et al. [25] reported that the total thickness of the leaf and epidermis of plants growing under shade were much lower than in non-shaded plants.

The leaf structure of ninebark Diable D'Or Mindia plants grown under natural conditions in soil was typical for mesophyll deciduous shrubs, being built of such tissues as epidermis (adaxial and abaxial), mesophyll (palisade and spongy parenchyma), and conductive bundles [26]. Its total thickness in plants from soil was $42 \%$ larger than that in plants in vitro. Both epidermis layers were little differentiated in ninebark cultured under different conditions, with the abaxial epidermis being thinner than the adaxial epidermis, both in in vivo and in vitro plants, as reported in crambe. However, in crambe, the thickness of both epidermis layers in plants in vitro were lower as compared to plants in vivo [5].

The mesophyll of ninebark leaves from soil was thicker than that from in vitro culture. The palisade parenchyma (PP) in plants from soil consisted of 2-3 layers and was 240\% thicker than that in vitro, where it had a single layer. Similar observations were noted in crambe [5]; and by Apóstolo et al. [27] in Cynara scolymus L., where the in vitro leaves tended to have a single layer of the palisade parenchyma. Similar observations on the mesophyll structure, i.e., poorly developed palisade parenchyma in in vitro plants, were reported by Kumar and Rao [28]. Additionally, in Nepeta nuda L. the leaf blade of the in vitro cultured plants was thinner than in the soil grown plants, being composed of one layer of very short palisade cells and two layers of spongy cells, while the soil-grown plants had two and 3-4 parenchyma layers, respectively [29]. In ninebark, also the spongy parenchyma (SP) was thicker in the field-grown plants-by $84 \%$ relative to plants from in vitro, where it was more loosely packed with wide air spaces. A comparison of the leaf anatomy in the in vitro cultured and field-grown plants of Vaccinium corymbosum L. [30] 
showed a similar pattern. In N. nuda L., plants adapted to ex vitro conditions formed leaves with equal thickness of leaf lamina and similar histological organization as the in vivo plants [29]. Unlike in herbaceous nepeta, woody ninebark leaf structure after eight weeks of acclimatization under standard conditions (no supplemental light and no ABA treatment) differed little relative to plants from in vitro.

In micropropagated ninebark, supplemental light had little effect on leaf anatomy during acclimation although it significantly increased the levels of the assimilation pigments. However, light conditions modified the effects of the ABA application: ninebark leaves of plants sprayed with ABA during acclimation were thicker under natural light. ABA as an antitranspirant is responsible for reducing water losses from leaves [19] but unfortunately, stomata were not counted nor measured in this experiment. We may only speculate that the positive effect of $\mathrm{ABA}$ in micropropagated ninebark was due to reduced transpiration but also stimulation of leaf growth, evident under poorer light conditions. Observations made here clearly confirm the general rules of acclimation established on a wide range of plant species, in that both ABA and light contribute to a better plant survival ex vitro and they show that ninebark follows the same rules.

\section{Conclusions}

Leaves from the in vitro plants were about two times thinner than those from outdoor grown plants, having only a single layer of the palisade parenchyma. ABA tended to increase the thickness of the palisade and spongy parenchyma but only in plants grown under natural light. Supplemental lighting during acclimation to the ex vitro conditions significantly increased the percentage of acclimated plants, plant height, and the internode number. ABA $\left(1 \mathrm{mg} \cdot \mathrm{L}^{-1}\right)$ treatment also positively affected plant growth. During acclimation, the photosynthesis rate increased while that of transpiration and stomatal conductance decreased. Supplemental lighting increased the contents of the assimilation pigments while the ABA treatment did not affect the chlorophyll $\mathrm{a}+\mathrm{b}$ concentration. ABA applied during acclimation on plants growing under both the natural light and with supplemental light increased the photosynthetic rate, reduced transpiration, and stomatal conductance relative to water controls. In conclusion, supplemental light and treatment with ABA enhance acclimation of micropropagated ninebark plants. In practical application in commercial production of ninebark, the recommendation based on this study is to spray cuttings with $1 \mathrm{mg} \cdot \mathrm{L}^{-1}$ and to provide supplemental lighting during the acclimation period.

Author Contributions: Conceptualization, K.J.-K. and A.J.Ł.; methodology, K.J.-K. and A.P.; formal analysis, K.J.-K., K.N. and A.P.; investigation, K.J.-K.; writing-original draft preparation, K.N. and A.J.Ł.; writing-review and editing, K.N., A.P. and A.J.Ł.; visualization, K.J.-K. and A.P.; supervision, A.J.Ł. All authors have read and agreed to the published version of the manuscript.

Funding: This research received no external funding.

Institutional Review Board Statement: Not applicable.

Informed Consent Statement: Not applicable.

Data Availability Statement: Not applicable.

Conflicts of Interest: The authors declare no conflict of interest.

\section{References}

1. Pospisilova, J.; Ticha, I.; Kadlecek, P.; Haisel, D.; Plzakova, S. Acclimatization of micropropagated plants to ex vitro conditions. Biol. Plant. 1999, 42, 481-497. [CrossRef]

2. Hazarika, B.N. Acclimatization of tissue-cultured plants. Curr. Sci. 2003, 85, 1704-1712.

3. Chandra, S.; Bandopadhyay, R.; Kumar, V.; Chandra, R. Acclimatization of tissue cultured plantlets: From laboratory to land. Biotechnol. Lett. 2010, 32, 1199-1205. [CrossRef] [PubMed]

4. Clapa, D.; Fira, A.; Joshee, N. An efficient ex vitro rooting and acclimatization method for horticultural plants using float hydroculture. HortScience 2013, 48, 1159-1167. [CrossRef] 
5. Werner, E.T.; Rozindo Dias Milanez, C.; Barcelos Passos Lima Gontijo, A.; Bastos Soares, T.C.; Teixeira do Amaral, J.A. Leaf anatomy changes related to cultivate in vivo and in vitro and during pre-acclimatization of Crambe abyssinica Hochst. Plant Cell Cult. Micropropag. 2018, 14, 10-17.

6. Aguilar, M.L. The role of abscisic acid in controlling leaf water loss, survival and growth of micropropagated Tagetes erecta plants when transferred directly to the field. J. Exp. Bot. 2000, 51, 1861-1866. [CrossRef]

7. Boursiac, Y.; Léran, S.; Corratgé-Faillie, C.; Gojon, A.; Krouk, G.; Lacombe, B. ABA transport and transporters. Trends Plant Sci. 2013, 18, 325-333. [CrossRef]

8. Mittler, R.; Blumwald, E. The roles of ROS and ABA in systemic acquired acclimation. Plant Cell 2015, 27, 64-70. [CrossRef]

9. Nowakowska, K.; Bodych, A.; Latkowska, M.; Pacholczak, A. The use of tissue cultures in the mass production of Heuchera'Silver Scrolls'. Ann. Warsaw Univ. Life Sci. SGGW Hortic. Landsc. Archit. 2020, 16, 5-16. [CrossRef]

10. Choudhury, F.K.; Rivero, R.M.; Blumwald, E.; Mittler, R. Reactive oxygen species, abiotic stress and stress combination. Plant J. 2017, 90, 856-867. [CrossRef]

11. Seon, J.H.; Cui, Y.Y.; Kozai, T.; Paek, K.Y. Influence of in vitro growth conditions on photosynthetic competence and survival rate of Rehmannia glutinosa plantlets during acclimatization period. Plant Cell. Tissue Organ Cult. 2000, 61, 135-142. [CrossRef]

12. Pacholczak, A.; Szydło, W. Effect of ammonium zinc acetate on rooting of stem cuttings in Physocarpus opulifolius. Ann. Warsaw Univ. Life Sci. SGGW. Hortic. Landsc. Archit. 2008, 29, 59-64.

13. Jagiełło-Kubiec, K.; Nowakowska, K.; Ilczuk, A.; Łukaszewska, A.J. Optimizing micropropagation conditions for a recalcitrant ninebark (Physocarpus opulifolius L. maxim.) cultivar. Vitr. Cell. Dev. Biol. Plant 2021. [CrossRef]

14. Lichtenthaler, H.K.; Wellburn, A.R. Determinations of total carotenoids and chlorophylls a and b of leaf extracts in different solvents. Biochem. Soc. Trans. 1983, 11, 591-592. [CrossRef]

15. Jensen, W.A. Botanical Histochemistry: Principles and Practice; W.H. Freeman and Co: San Francisco, CA, USA, 1962.

16. Wójcik, A.R.; Laudański, Z. Planowanie i wnioskowanie statystyczne w doświadczalnictwie. In Statistical Planning and Concluding in Experimental Works; Państwowe Wydawnictwo Naukowe: Warszawa, Poland, 1989; ISBN 8301089946/9788301089948.

17. Rai, M.K.; Shekhawat, N.S.; Harish Gupta, A.K.; Phulwaria, M.; Ram, K.; Jaiswal, U. The role of abscisic acid in plant tissue culture: A review of recent progress. Plant Cell. Tissue Organ Cult. 2011, 106, 179-190. [CrossRef]

18. Pospisilova, J.; Haisel, D.; Synkova, H.; Batkova-Spoustova, P. Improvement of ex vitro transfer of tobacco plantlets by addition of abscisic acid to the last subculture. Biol. Plant. 2009, 53, 617-624. [CrossRef]

19. Pospíšilová, J.; Synková, H.; Haisel, D.; Semorádová, Š. Acclimation of plantlets to Ex vitro conditions: Effects of air humidity, irradiance, $\mathrm{CO} 2$ concentration and abscisic acid (a Review). Acta Hortic. 2007, 748, 29-38. [CrossRef]

20. Dias, M.C.; Correia, C.; Moutinho-Pereira, J.; Oliveira, H.; Santos, C. Study of the effects of foliar application of ABA during acclimatization. Plant Cell. Tissue Organ Cult. 2014, 117, 213-224. [CrossRef]

21. Vilela, B.J.; Carvalho, L.C.; Ferreira, J.; Amâncio, S. Gain of function of stomatal movements in rooting Vitis vinifera L. plants: Regulation by H2O2 is independent of ABA before the protruding of roots. Plant Cell Rep. 2007, 26, 2149-2157. [CrossRef]

22. Adams, S.R.; Langton, F.A. Photoperiod and plant growth: A review. J. Hortic. Sci. Biotechnol. 2005, 80, 2-10. [CrossRef]

23. Kubínová, L. Stomata and Mesophyll Characteristics of Barley Leaf as Affected by Light: Stereological Analysis. J. Exp. Bot. 1991, 42, 995-1001. [CrossRef]

24. Amiard, V.; Mueh, K.E.; Demmig-Adams, B.; Ebbert, V.; Turgeon, R.; Adams, W.W. Anatomical and photosynthetic acclimation to the light environment in species with differing mechanisms of phloem loading. Proc. Natl. Acad. Sci. USA 2005, 102, 12968-12973. [CrossRef]

25. Han, C.; Yu, M.; Wang, Q.; Wang, L.; Yang, H.; Zhao, Y.; Dong, H. Leaf structure and seed histochemistry analyses provided structural insights into the improved yield and quality of tree peony seed under light shading conditions. Sci. Rep. 2020, 10, 4328. [CrossRef]

26. Balsamo, R.A.; Bauer, A.M.; Davis, S.D.; Rice, B.M. Leaf biomechanics, morphology, and anatomy of the deciduous mesophyte Prunus serrulata (Rosaceae) and the evergreen sclerophyllous shrub Heteromeles arbutifolia (Rosaceae). Am. J. Bot. 2003, 90, 72-77. [CrossRef]

27. Apóstolo, N.M.; Brutti, C.B.; Llorente, B.E. Leaf anatomy of Cynara scolymus L. in successive micropropagation stages. Vitr. Cell. Dev. Biol. Plant 2005, 41, 307-313. [CrossRef]

28. Kumar, K.; Rao, I.U. Morphophysiologicals problems in acclimatization of micropropagated plants in-ex vitro conditions- a reviews. J. Ornam. Hortic. Plants 2012, 2, 271-283.

29. Dragolova, D.; Stefanova, M.; Dimitrova, M.; Koleva, D.; Zhiponova, M.; Kapchina-Toteva, V. In vitro cultivation and ex vitro adaptation of nepeta nuda SSP. Nuda-correlation between regeneration potential, leaf anatomy, and plastid pigments. Bulg. J. Agric. Sci. 2015, 21, 1027-1032.

30. Noe, N.; Bonini, L. Leaf anatomy of highbush blueberry grownin vitro and during acclimatization toex vitro conditions. Biol. Plant. 1996, 38, 19-25. [CrossRef] 